\title{
Metronidazole in the treatment of non-specific vaginitis (NSV)
}

\author{
F JERVE, T B BERDAL, P BOHMAN, Chr CAPPELEN SMITH, O K EVJEN, \\ H GJ $\varnothing$ NNAESS, M GAASEMYR, L HAUSKEN, K HESLA, E HOFTVEDT, P H $\varnothing$ VIK, \\ J KAHN, R M KARLSEN, S LIE, B L $\phi V L A N D, H$ B L $\phi V L A N D, P$ NORDMARK, \\ T SALTVEIT, $\varnothing$ SANDE, J STEIER, T WINGE, B YSTEHEDE, AND E QVIGSTAD
}

From the Department of Gynaecology and Obstetrics, Ulleval Hospital, Oslo, Norway

SUMMARY In a large multicentre study of 429 patients with the usual signs and symptoms of non-specific vaginitis (NSV), we studied the effect of different doses of metronidazole. The patients were divided into five treatment groups as follows: group A was given $400 \mathrm{mg}$ metronidazole three times daily for seven days, group B $2000 \mathrm{mg}$ as a single dose, group C $2000 \mathrm{mg}$ on days 1 and 2, group D $2000 \mathrm{mg}$ on days 1 and 3, and group E was given $1200 \mathrm{mg}$ metronidazole once daily for five days. At follow up examination four weeks from the start of treatment, patients in groups $\mathrm{D}$ and $\mathrm{E}$ showed the best clinical results with cure rates of $94 \cdot 0 \%$ and 93.6\% respectively. In addition the rate of reisolation of Gardnerella vaginalis was lowest in group D. We therefore recommend metronidazole $2000 \mathrm{mg}$ on days 1 and 3 as routine treatment for non-specific or vaginitis associated with gardnerella.

\section{Introduction}

Since the initial clinical report of Gardner and Dukes in $1955,{ }^{1}$ non-specific vaginitis (NSV) has been recognised as a clinical entity. It has been described under different names and at present the condition is most commonly called bacterial vaginosis ${ }^{2}$ or vaginitis associated with gardnerella. ${ }^{3}$ It is probably related to the isolation of Gardnerella vaginalis, but other micro-organisms such as different anaerobic bacteria and so called comma shaped rods ${ }^{3}$ may be involved in the pathogenesis of the condition. There seems, however, to be a definite clinical condition, which is characterised by the following criteria: homogeneous, non-adherent vaginal discharge; $\mathrm{pH}$ of vaginal discharge $>4 \cdot 5-5 \cdot 0$; presence of clue cells in the discharge; amine-like smell after addition of $10 \%$ potassium hydroxide to the discharge. The clinical diagnosis of NSV requires that at least three of these criteria are present, ${ }^{2}$ and $G$ vaginalis can be cultured from vaginal material from most patients with NSV. ${ }^{3}$

The vaginal use of sulpha creams was initially considered suitable treatment for $\mathrm{NSV},{ }^{1}$ but since the

Address for reprints: Dr F Jerve, Department of Gynaecology and Obstetrics, Ulleval Hospital, Oslo, Norway

Accepted for publication 13 September 1983 studies of Pheifer et al, ${ }^{4}$ Balsdon et al, ${ }^{5}$ and Malouf et $a l,{ }^{6}$ metronidazole is now considered the drug of choice for NSV. This paper reports the results of a multicentre study in which patients were treated with different doses of metronidazole over different periods of time.

\section{Patients, materials, and methods}

We studied 429 patients with a clinical diagnosis of NSV based on the presence of at least three of the four clinical criteria cited above. Material from the vagina was sent to the laboratory in Stuart's transport medium and cultured for $G$ vaginalis, Neisseria gonorrhoeae, Trichomonas vaginalis, and Candida albicans. $G$ vaginalis was identified by the method described by Shaw et $\mathrm{al}^{7}$; other bacteria were identified by routine laboratory procedures. Samples were also taken from some patients for isolation of anaerobic microbes. The amine test was performed by adding $10 \%$ potassium hydroxide to a sample of vaginal discharge, and the vaginal $\mathrm{pH}$ was measured by inserting a piece of $\mathrm{pH}$ paper into the vagina using a speculum. Clue cells were examined by microscopy after adding $0.9 \%$ saline to the vaginal discharge. Patients with positive cultures for $N$ gonorrhoeae or $T$ vaginalis were excluded from the study.

The patients were divided into five different treatment groups and given metronidazole as 
follows: group $A(n=97) 400 \mathrm{mg}$ three times daily for seven days; group $B(n=83) 2000 \mathrm{mg}$ as a single dose; group $C(n=84) 2000 \mathrm{mg}$ on days 1 and 2; group $D(n=85) 2000 \mathrm{mg}$ on days 1 and 3; and group $E(n=80) 1200 \mathrm{mg}$ once daily for five days. Four weeks after the start of treatment the patients were reassessed, and cultures and tests performed as at the first attendance. Sexual partners were given the same treatment as the patients. At follow up the patients were assessed as cured or not by the examining doctor according to the criteria for NSV. They were also asked to state whether they considered themselves cured or not.

All tests used in analysis of the results were one tailed. ${ }^{10}$ Differences with $p<5$ were considered significant. The Wilcoxon rank sum test and signed midrank test were used to compare $\mathrm{pH}$ levels in, and changes within, treatment groups. Confidence intervals were calculated according to the BernoulliWilcoxon procedure, ${ }^{8}$ and $95 \%$ confidence intervals of frequencies are calculated according to the theory of simple Bernoulli sequences. ${ }^{9}$ Fisher's exact test and McNemar's test were used to comparefrequencies in, and changes within, treatment groups.

\section{Results}

Table I shows the ages of our patients and duration of their symptoms before treatment. The ages were similar in all groups, but the duration of symptoms varied as some groups included patients with symptoms of very long duration. In all five groups of patients, after treatment there were significant $(p<0.01)$ reductions in the frequency of malodour, the amount of vaginal discharge, and in the intensity of amine smell on addition of $10 \%$ potassium hydroxide (data not shown). Table II shows that there also was a significant $(p<0.01)$ reduction in the $\mathrm{pH}$ of the vaginal discharge in all groups. In table III the frequency of isolation of $G$ vaginalis before and after treatment is shown. A significant reduction $(p<0.01)$ in isolation after treatment was found in all groups, being most evident in group $D$.

TABLE I Mean (range) ages and duration of symptoms of 429 patients with NSV

\begin{tabular}{llll}
\hline Group & $\begin{array}{l}\text { Treatment with } \\
\text { metronidazole }\end{array}$ & Ages in years & $\begin{array}{l}\text { Days' duration } \\
\text { of symptoms }\end{array}$ \\
\hline A $(\mathrm{n}=9 ;)$ & $\begin{array}{c}400 \mathrm{mg} \text { thrice } \\
\text { daily for } 7 \text { days }\end{array}$ & $30(17-49)$ & $42(7-2400)$ \\
B (n=83) & $\begin{array}{c}2000 \mathrm{mg} \\
\text { in a single dose }\end{array}$ & $27(17-57)$ & $63(2-1000)$ \\
C (n=84) & $\begin{array}{c}2000 \mathrm{mg} \\
\text { on days 1 and 2 }\end{array}$ & $28(11-70)$ & $42(7-730)$ \\
D (n=85) & $\begin{array}{c}2000 \mathrm{mg} \\
\text { on days 1 and 3 }\end{array}$ & $32(17-52)$ & $\mathbf{4 2}(14-42)$ \\
E (n=80) & $\begin{array}{c}1200 \text { mg once } \\
\text { daily for 5 days }\end{array}$ & \\
\hline
\end{tabular}

TABLE II Vaginal pH in 429 patients with NSV before and after treatment

\begin{tabular}{|c|c|c|c|c|}
\hline \multirow[b]{2}{*}{ Group } & \multirow{2}{*}{$\begin{array}{l}\text { Treatment with } \\
\text { metronidazole }\end{array}$} & \multicolumn{2}{|c|}{ Mean (SD) pH } & \multirow{2}{*}{$\begin{array}{l}\text { Mean } \\
\text { reduction }\end{array}$} \\
\hline & & Before & After & \\
\hline$A(n=97)$ & $\begin{array}{l}400 \mathrm{mg} \text { thrice } \\
\text { daily for } 7 \text { days }\end{array}$ & $5 \cdot 8(0 \cdot 1)$ & $5 \cdot 0(0 \cdot 2)$ & $0.8(p<0.01)$ \\
\hline$B(n=83)$ & $\begin{array}{l}2000 \mathrm{mg} \\
\text { in a single dose }\end{array}$ & $5 \cdot 6(0 \cdot 1)$ & $4 \cdot 8(0 \cdot 1)$ & $0.7(p<0.01)$ \\
\hline$C(n=84)$ & $\begin{array}{l}2000 \mathrm{mg} \\
\text { on days } 1 \text { and } 2\end{array}$ & $5 \cdot 6(0 \cdot 1)$ & $4 \cdot 7(0 \cdot 1)$ & $0.9(p<0.01)$ \\
\hline$D(n=85)$ & $\begin{array}{l}2000 \mathrm{mg} \\
\text { on days } 1 \text { and } 3\end{array}$ & $5 \cdot 8(0 \cdot 1)$ & $4 \cdot 8(0 \cdot 1)$ & $1.2(p<0.01)$ \\
\hline$E(n=80)$ & $\begin{array}{l}1200 \mathrm{mg} \text { once } \\
\text { daily for } 5 \text { days }\end{array}$ & $5 \cdot 8(0 \cdot 1)$ & $4 \cdot 7(0 \cdot 1)$ & $1.1(p<0.01)$ \\
\hline
\end{tabular}

TABLE III Isolation of $G$ vaginalis from 429 patients with NSV before and after treatment

\begin{tabular}{lllll}
\hline & $\begin{array}{l}\text { Treatment with } \\
\text { metronidazole }\end{array}$ & \multicolumn{2}{l}{ No positive } & \\
\cline { 3 - 4 } & Before & After & Significance \\
\hline A $(\mathrm{n}=97)$ & $\begin{array}{c}400 \mathrm{mg} \text { thrice } \\
\text { daily for } 7 \text { days }\end{array}$ & 90 & 15 & $(\mathrm{p}<0.01)$ \\
B $(\mathrm{n}=83)$ & $\begin{array}{c}2000 \mathrm{mg} \\
\text { in a single dose }\end{array}$ & 81 & 15 & $(\mathrm{p}<0.01)$ \\
C $(\mathrm{n}=84)$ & $\begin{array}{c}2000 \mathrm{mg} \\
\text { on days } 1 \text { and } 2\end{array}$ & 82 & 21 & $(\mathrm{p}<0.01)$ \\
D $(\mathrm{n}=85)$ & $\begin{array}{c}2000 \mathrm{mg} \\
\text { on days } 1 \text { and } 3\end{array}$ & 74 & 6 & $(\mathrm{p}<0.01)$ \\
E $(\mathrm{n}=80)$ & $\begin{array}{c}1200 \mathrm{mg} \text { once } \\
\text { daily for } 5 \text { days }\end{array}$ & 78 & 19 & $(\mathrm{p}<0.01)$ \\
Total & 429 & 405 & 76 & $(\mathrm{p}<0.01)$ \\
\hline
\end{tabular}

Table IV shows the estimate of probability of the eradication of $G$ vaginalis after treatment, as well as the $\mathbf{9 5 \%}$ confidence interval estimate for that probability in each group. Again group $D$, in which patients were given $2000 \mathrm{mg}$ metronidazole on days 1 and 3, showed the highest cure rate. Tables V and VI show the probability of the cure rate in each group, as estimated by the examining doctor and by the patient herself, and the estimate of the $95 \%$ confidence interval for each probability. Again

TABLE IV Probability of eradication of $G$ vaginalis from 429 patients with NSV

\begin{tabular}{llll}
\hline Group & $\begin{array}{l}\text { Treatment with } \\
\text { metronidazole }\end{array}$ & $\begin{array}{c}\% \text { point } \\
\text { estimate }\end{array}$ & $\begin{array}{l}95 \% \text { confidence } \\
\text { interval (\%) }\end{array}$ \\
\hline A $(\mathrm{n}=97)$ & $\begin{array}{c}400 \mathrm{mg} \text { thrice } \\
\text { daily for } 7 \text { days }\end{array}$ & $82 \cdot 4$ & $73 \cdot 3-89 \cdot 6$ \\
B $(\mathrm{n}=83)$ & $\begin{array}{c}2000 \mathrm{mg} \\
\text { in a single dose }\end{array}$ & $81 \cdot 7$ & $71 \cdot 3-89 \cdot 1$ \\
C $(\mathrm{n}=84)$ & $\begin{array}{c}2000 \mathrm{mg} \\
\text { on days } 1 \text { and } 2\end{array}$ & $74 \cdot 1$ & $62 \cdot 9-82 \cdot 9$ \\
D $(\mathrm{n}=85)$ & $\begin{array}{c}2000 \mathrm{mg} \\
\text { on days } 1 \text { and 3 }\end{array}$ & $92 \cdot 4$ & $83 \cdot 2-96 \cdot 8$ \\
E $(\mathrm{n}=80)$ & $\begin{array}{c}1200 \mathrm{mg} \text { once } \\
\text { daily for 5 days }\end{array}$ & $75 \cdot 6$ & $64 \cdot 4-84 \cdot 3$ \\
\hline
\end{tabular}


TABLE V Probability of cure rates in 429 patients with NSV as estimated by the doctor

\begin{tabular}{llll}
\hline Group & $\begin{array}{l}\text { Treatment with } \\
\text { metronidazole }\end{array}$ & $\begin{array}{l}\% \text { point } \\
\text { estimate }\end{array}$ & $\begin{array}{l}95 \% \text { confidence } \\
\text { interval (\%) }\end{array}$ \\
\hline A $(\mathrm{n}=97)$ & $\begin{array}{c}400 \mathrm{mg} \text { thrice } \\
\text { daily for } 7 \text { days }\end{array}$ & $86 \cdot 6$ & $\mathbf{7 7 \cdot 8 - 9 2 \cdot 4}$ \\
B $(\mathrm{n}=83)$ & $\begin{array}{c}2000 \mathrm{mg} \\
\text { in a single dose }\end{array}$ & $84 \cdot 3$ & $74 \cdot 3-91 \cdot 1$ \\
$\mathrm{C}(\mathrm{n}=84)$ & $\begin{array}{c}2000 \mathrm{mg} \\
\text { On days } 1 \text { and } 2\end{array}$ & $81 \cdot 2$ & $70 \cdot 9-88 \cdot 5$ \\
$\mathrm{D}(\mathrm{n}=85)$ & $\begin{array}{c}2000 \mathrm{mg} \\
\text { on days } 1 \text { and } 3\end{array}$ & $94 \cdot 0$ & $85 \cdot 9-97 \cdot 6$ \\
$\mathrm{E}(\mathrm{n}=80)$ & $\begin{array}{c}1200 \text { mg once } \\
\text { daily for } 5 \text { days }\end{array}$ & $93 \cdot 6$ & $85 \cdot 0-97 \cdot 6$ \\
\hline
\end{tabular}

TABLE VI Probability of cure rates in 429 patients with NSV as estimated by the patient

\begin{tabular}{llll}
\hline Group & $\begin{array}{l}\text { Treatment with } \\
\text { metronidazole }\end{array}$ & $\begin{array}{l}\% \text { point } \\
\text { estimate }\end{array}$ & $\begin{array}{l}95 \% \text { confidence } \\
\text { interval (\%) }\end{array}$ \\
\hline A $(\mathrm{n}=97)$ & $\begin{array}{c}400 \mathrm{mg} \text { thrice } \\
\text { daily for } 7 \text { days }\end{array}$ & $80 \cdot 4$ & $70 \cdot 9-87 \cdot 5$ \\
B $(\mathrm{n}=83)$ & $\begin{array}{c}2000 \mathrm{mg} \\
\text { in a single dose }\end{array}$ & $80 \cdot 7$ & $71 \cdot 3-88 \cdot 3$ \\
C $(\mathrm{n}=84)$ & $\begin{array}{c}2000 \mathrm{mg} \\
\text { on days 1 and } 2\end{array}$ & $70 \cdot 6$ & $59 \cdot 6-79 \cdot 6$ \\
$\mathrm{D}(\mathrm{n}=85)$ & $\begin{array}{c}2000 \mathrm{mg} \\
\text { On days 1 and 3 }\end{array}$ & $89 \cdot 2$ & $79 \cdot 9-94 \cdot 6$ \\
$\mathrm{E}(\mathrm{n}=80)$ & $\begin{array}{c}1200 \text { mg once } \\
\text { daily for } 5 \text { days }\end{array}$ & $86 \cdot 3$ & $76 \cdot 3-92 \cdot 6$ \\
\hline
\end{tabular}

group D showed the highest cure rate, but this was only slightly better than in group $E$ and not significantly better than in the other groups.

Side effects were few and did not cause any of the patients to stop the treatment. A few patients complained of a metallic taste, but nausea was no problem in any of the groups. Table VII shows the isolation rates of $C$ albicans before and after treatment. Patients in groups $\mathrm{A}$ and $\mathrm{E}$, who were given the longest course of treatment, showed a significant $(p<0.01)$ increase in isolations, which was not observed with shorter treatment regimens. In a

TABLE VII Isolation of C albicans from 429 patients with $N S V$ before and after treatment

\begin{tabular}{lllll}
\hline & Treatment with & \multicolumn{2}{l}{ No positive } & \\
\cline { 3 - 4 } Group & metronidazole & Before & After & Significance \\
\hline A $(\mathrm{n}=97)$ & $\begin{array}{c}400 \mathrm{mg} \text { thrice } \\
\text { daily for } 7 \text { days }\end{array}$ & 5 & 15 & $\mathrm{p}<0.01$ \\
B $(\mathrm{n}=83)$ & $\begin{array}{c}2000 \mathrm{mg} \\
\text { in a single dose }\end{array}$ & 5 & 7 & $\mathrm{NS}$ \\
$\mathrm{C}(\mathrm{n}=84)$ & $\begin{array}{c}2000 \mathrm{mg} \\
\text { on days 1 and 2 }\end{array}$ & 4 & 8 & $\mathrm{p}=0.09$ \\
$\mathrm{D}(\mathrm{n}=85)$ & $\begin{array}{c}2000 \mathrm{mg} \\
\text { on days 1 and 3 }\end{array}$ & 6 & 4 & $\mathrm{NS}$ \\
$\mathrm{E}(\mathrm{n}=80)$ & $\begin{array}{c}1200 \mathrm{mg} \text { once } \\
\text { daily for 5 days }\end{array}$ & 3 & 13 & $\mathrm{p}<0.01$ \\
\hline
\end{tabular}

smaller group, 60 patients from group E, vaginal material was cultured for anaerobic bacteria. A significant reduction $(p<0.01)$ in the isolation rate was found after treatment (data not shown). The anaerobes most commonly cultured were Bacteroides species and anaerobic streptococci.

\section{Discussion}

There seems to be little doubt that metronidazole is the drug of choice for the treatment of NSV.4-6 As it is claimed to be a potentially dangerous drug, ${ }^{11}$ as low a dosage in as short a time as possible to gain satisfactory results should be used. Recent pharmacokinetic studies ${ }^{12}$ have shown that single oral doses of $1200-2000 \mathrm{mg}$ of metronidazole can give plasma and urine concentrations that exceed the minimum inhibitory concentration (MIC) for some strains of $G$ vaginalis. The importance of this is uncertain, as acceptable results have been achieved with lower doses of metronidazole when MICs for $G$ vaginalis in the plasma were not obtained.45 The satisfactory clinical results in these studies probably show the effect of metronidazole on anaerobic microorganisms, which may play a part in NSV. Another factor that might be important is the effect of the metabolite of metronidazole, 2-hydroxy-metronidazole, and of the high concentration of it in the urine. ${ }^{12}$

In this study the regimens in which metronidazole was given at a dosage of $\mathbf{4 0 0} \mathbf{m g}$ three times daily for seven days (group A), $2000 \mathrm{mg}$ daily on days 1 and 3 (group D) and $1200 \mathrm{mg}$ daily for five days (group E), all showed satisfactory clinical results with high cure rates. In the group of patients given $1200 \mathrm{mg}$ metronidazole daily for five days (group $E$ ) the reduction in the isolation of $G$ vaginalis was significantly $(\mathrm{p}<0 \cdot 01)$ lower than in the group given $2000 \mathrm{mg}$ on days 1 and 3. Treatment for five or seven days was associated with significantly increased isolation of $C$ albicans, probably due to the effect on the vaginal "ecosystem" of microflora. The clinical significance of increased $C$ albicans isolation is uncertain, but it seems to indicate a shorter treatment time.

We conclude that treatment of NSV with metronidazole $2000 \mathrm{mg}$ given in single doses on days 1 and 3 gives a high cure rate, has few side effects, and in most cases eradicates $G$ vaginalis. This regimen can be recommended as a routine treatment for nonspecific vaginitis associated with gardnerella.

\section{References}

1. Gardner HL, Dukes CD. Haemophilus vaginalis vaginitis: a newly defined specific infection previously classified "nonspecific" vaginitis. Am J Obstet Gynecol 1955;69:962-76. 
2. Vontver LA, Eschenbach DA. The role of Gardnerello vaginalis in non-specific vaginitis. Clin Obstet Gynecol 1981; 24:439-60.

3. Spiegel CA, Amsel R, Eschenbach DA, Schoenknecht F, Holmes KK. Anaerobic bacteria in non-specific vaginitis. $N$ Engl J Med 1980; 303:601-7.

4. Pheifer TA, Forsyth PS, Durfee MA, Pollock HM, Holmes KK. Non-specific vaginitis: role of Haemophilus vaginalis and treatment with metronidazole. N Engl J Med 1979; 298: 1429-34.

5. Balsdon MJ, Taylor GE, Pead L, Maskell R. Corynebacterium vaginale and vaginitis: a controlled trial of treatment. Lancet 1980 ; i: $501-4$.

6. Malouf $M$, Fortier M, Morin G, Dube J-L. Treatment of Haemophilus vaginalis vaginitis. Obstet Gynecol 1981;57: 711-4.
7. Shaw CE, Forsyth ME, Bowie WR. Rapid presumptive identification of Gardnerella vaginalis (Haemophilus vaginalis) from human blood agar media. J Clin Microbiol 1981; 14: 108-10.

8. Lehmann EL. Nonparametrics: statistical methods based on ranks. San Francisco: Holden-Day, 1975.

9. Jendall $M$, Stuart A. The advanced theory of statistics, II. London: Charles Griffin, 1960.

10. Sverdrup E. Significance testing in multiple statistical inference. Scandinavian Journal of Statistics 1975; 3:73-8.

11. Goldman P. Drug therapy: metronidazole. $N$ Engl J Med 1980; 303: 1212-7.

12. Easmon CSF, Ison CA, Kaye CM, Timewell RM, Dawson SG. Pharmacokinetics of metronidazoleand its principal metabolites and their activity against Gardnerella vaginalis. Br J Vener Dis 1982; 58:246-9. 